\title{
Economic Comparison of Divergent Strains of Holstein-Friesian Cows in Various Pasture-Based Production Systems
}

\author{
S. McCarthy, ${ }^{\dagger} \dagger^{1}$ B. Horan, ${ }^{*} \dagger$ P. Dillon, ${ }^{*}$ P. O'Connor, ${ }^{*}$ M. Rath, $\dagger$ and L. Shalloo* \\ *Moorepark, Dairy Production Research Centre, Fermoy, Co. Cork, Ireland \\ †School of Agriculture, Food Science \& Veterinary Medicine, University College Dublin, Belfield, Dublin 4, Ireland
}

\begin{abstract}
The objective of this paper was to compare the economic efficiency of 3 divergent strains of HolsteinFriesian cows-high-production North American (HP), high-durability North American (HD), and New Zealand (NZ) - across a variety of Irish pasture-based production systems: Moorepark (MP), high concentrate (HC), and high stocking rate (HS). Physical performance data were obtained from a 5-yr study conducted previously. The economic performance of each strain and feed system was derived for 3 production scenarios: European Union (EU) milk quota applied at the farm level using predicted future prices and costs (S1); EU milk quota applied at the industry level, thus permitting quota leasing at predicted future prices and costs (S2); and EU milk quota applied at the industry level with a limitation on land availability (S3). The economic results showed that in a fixed milk quota scenario, the $\mathrm{NZ}$ strain in the MP and HS feed systems returned the highest profitability. The HD strain in the MP and HS feed systems proved the next most profitable, whereas the HP animals were least profitable in all feed systems. Similar to S1, in S2 the NZ were most profitable; however, the difference between the MP and HS was much smaller. The HP strain proved least profitable in all feed systems. In S3, the NZ strain was again most profitable; however, within that scenario the HS feed system was optimal. These results show that exclusive genetic selection for increased milk production results in reduced farm profitability because the productivity gains achieved are outweighed by associated increases in reproductive wastage costs in a pasture-based system. These results reinforce the economic value of genetic improvement based on a selection index encompassing traits of economic significance pertinent to the production environment.
\end{abstract}

Key words: Holstein-Friesian strain, economic scenario, pasture-based system

Received August 11, 2006.

Accepted November 13, 2006

${ }^{1}$ Corresponding author: Sean.mccarthy@teagasc.ie

\section{INTRODUCTION}

The Irish dairy industry will experience considerable change in the years ahead (Hennessey and Thorne, 2006). Among the main agents of change, reform of European Union (EU) agricultural policy, increased environmental regulation, and economic prosperity will dramatically change the production landscape. The challenge for Irish dairy farmers is to increase the competitiveness of their business through innovation, productivity gain, and increased operational scale as the industry evolves (Shalloo et al., 2004b). Genetic improvement of the dairy herd is one avenue to increased profitability on Irish dairy farms (Veerkamp et al., 2002) in a more competitive international dairy production environment.

To evaluate the economic effects of animal performance variation arising from various alternate genetic selection strategies, a comprehensive multidisciplinary systems approach is required that incorporates the effects on all major farm components, including production revenues as well as variable and fixed costs. Agricultural policy has major implications for the evolution of production systems. The continued pressures for reform of EU agricultural policy (Common Agricultural Policy) aimed at reducing barriers to trade between EU and other markets are likely to change the production landscape dramatically for EU producers. Such reforms are likely to result in a single world market-focused dairy industry free from milk quota restrictions, which are currently in place until 2014, and protectionism in which farm gate prices to EU producers will reduce and become more volatile, in line with world markets (Dillon et al., 2005). The consequences of various genetic selection strategies must therefore be appraised with due consideration to future agricultural policy outcomes.

Until recently, milk yield has been the main objective criterion for selection in most temperate countries, and the use of Holstein-Friesian genetics of North American ancestry has been ubiquitous. The popularity of the North American Holstein-Friesian most likely occurred because of its increased productivity over other dairy breeds in a market that rewarded milk volume with little incentive for milk solids content. With overwhelm- 
ing evidence now showing antagonistic associations between production and health traits (Evans et al., 2004; Horan et al., 2004; Rauw et al., 1998), continued selection for greater milk yield is anticipated to have deleterious consequences for the health and fitness of the dairy herd (Pryce and Veerkamp, 2001).

The optimal genetics for any given system of production is that which results in the greatest overall profit within that environment. Such genetics can only be identified by combining all traits (production and health) of economic significance in a weighted index of economic merit pertinent to that production environment and by selecting sires from the top of this index. In pastoral dairy systems such as in Ireland, it has been proved that optimal profitability is achieved through the maximal exploitation of cheap, high-quality grazed grass in the diet of the dairy cow (Shalloo et al., 2004b; Dillon et al., 2005). In such systems in which breeding and calving are restricted to a limited time period of the year, the relative importance of fertility is greater (Veerkamp et al., 2002). Reproductive performance affects the amount of milk produced per cow per day of herd life, breeding costs, rate of voluntary and involuntary culling, and rate of genetic progress for traits of importance (Plaizier et al., 1997; Lopez-Villalobos et al., 2000), and has a significant effect on the overall profitability of a dairy herd (Britt, 1985). The Economic Breeding Index (EBI) was introduced in Ireland in 2001 to identify genetically superior animals to increase profitability within Irish dairy herds (Veerkamp et al., 2002). The EBI is currently composed of 5 subindexes (relative emphasis in parentheses): milk production (49\%), fertility/survival (32\%), calving performance $(8 \%)$, beef performance $(6 \%)$, and health $(5 \%)$.

The objective of the present paper was to investigate the profitability of 3 strains of Holstein-Friesian dairy cows differing in genetic potential for milk production and reproductive performance across 3 pasture-based production systems based on various alternate production scenarios arising from changes in EU agricultural policy.

\section{MATERIALS AND METHODS}

\section{Production Study Details}

The design of the 5-yr study and a subset of the production and reproduction data used in the analysis of the various strains and systems of production in the present evaluation were reported by Horan et al. (2004, 2005). Briefly, 3 strains of Holstein-Friesian cows were compared: high-production North American (HP), highdurability North American (HD), and New Zealand (NZ). The HP strain was chosen on the basis of a superior pedigree index for milk production, whereas the
Table 1. Mean pedigree index for 3 strains of Holstein-Friesian cows studied based on their predicted transmitting abilities (and SD) for milk production, survival, and calving interval ${ }^{1}$

\begin{tabular}{lccc}
\hline Item & $\begin{array}{c}\text { High } \\
\text { production }\end{array}$ & $\begin{array}{c}\text { High } \\
\text { durability }\end{array}$ & $\begin{array}{c}\text { New } \\
\text { Zealand }\end{array}$ \\
\hline Milk, kg & $+194(90.8)$ & $+76(61.4)$ & $+52(56.0)$ \\
Fat, kg & $+9.0(2.96)$ & $+6.3(2.84)$ & $+8.6(2.66)$ \\
Protein, kg & $+8.8(2.39)$ & $+5.7(1.58)$ & $+4.2(1.33)$ \\
Fat, g/kg & $+0.3(0.53)$ & $+0.7(0.56)$ & $+1.3(0.58)$ \\
Protein, g/kg & $+0.4(0.23)$ & $+0.6(0.30)$ & $+0.5(0.21)$ \\
Survival, \% & $-0.5(1.11)$ & $+0.4(0.51)$ & $+1.2(0.62)$ \\
Calving interval, d & $+0.44(1.57)$ & $-1.2(0.71)$ & $-1.6(0.86)$ \\
Overall EBI, $^{2} €$ & 51 & 58 & 75 \\
Subindices $^{3}$ & & & \\
Milk, $€$ & 46 & 32 & 41 \\
Fertility, $€$ & 2 & 25 & 38 \\
Calving, $€$ & 2 & 0 & 5 \\
Health, $€$ & -2 & 0 & -5 \\
Beef, $€$ & 1 & 1 & -9 \\
\hline
\end{tabular}

${ }^{1}$ All predicted differences were obtained from the February 2004 international evaluations of the Interbull Animal Center (Uppsala, Sweden) using the MACE (Multitrait Across-Country Evaluation).

${ }^{2} \mathrm{EBI}=$ Economic Breeding Index.

${ }^{3}$ Subindices were derived from the economic values of individual traits: milk $(-€ 0.084 / \mathrm{kg})$ fat, $(€ 1.55 / \mathrm{kg})$, protein $(€ 5.27 / \mathrm{kg})$, survival $(€ 10.80 / \%)$, calving interval ( $€ 7.17 / \mathrm{d})$, health $(-€ 55.48 /$ unit logSCC and $€ 1.13 /$ standardized locomotion score), beef ( $€ 2.94$ ).

HD strain was selected on the basis of a superior pedigree index for milk production, fertility, and muscularity traits. The NZ strain was selected using the highest possible genetic merit expressed in the New Zealand genetic evaluation system (Breeding Worth). Primiparous animals entering the herd from spring 2003 onward were bred from within each strain using sires concurrent with the different breeding objectives outlined above relative to that strain. Each strain represented, on average, 13 sires over the 5 yr of the study. The mean pedigree index (from the February 2004 international evaluations of the Interbull Animal Center, Uppsala, Sweden) for each strain is displayed in Table 1.

Each strain was allocated to one of 3 feed systems (FS); high milk output per cow from pasture (MP), highconcentrate FS at pasture (HC), and high milk output per unit area from pasture (HS). The MP system had an overall stocking rate of 2.47 cows/ha, had a $\mathrm{N}$ fertilizer input of $290 \mathrm{~kg}$ of N/ha, and received $325 \mathrm{~kg}$ of concentrate/cow in early lactation, with the remainder of the lactation diet composed of grazed grass. The HC feed system had a similar overall stocking rate and $\mathrm{N}$ input as the MP feed system but $1,445 \mathrm{~kg}$ of concentrate/cow was fed. The HS group had similar concentrate (327 $\mathrm{kg} / \mathrm{cow}$ ) and $\mathrm{N}$ inputs as the MP system but had an overall stocking rate of $2.74 \mathrm{cows} / \mathrm{ha}$. The MP and HC systems were designed to allow each strain to express its potential within each feed system largely un- 
Table 2. The effect of strain of Holstein-Friesian ${ }^{1}$ on milk production, BW, and reproductive performance in the Moorepark (MP), highconcentrate (HC), and high-stocking-rate (HS) feeding systems

\begin{tabular}{|c|c|c|c|c|c|c|c|c|c|}
\hline Effect & \multicolumn{3}{|c|}{ MP } & \multicolumn{3}{|c|}{$\mathrm{HC}$} & \multicolumn{3}{|c|}{ HS } \\
\hline $\begin{array}{l}\text { Number of lactations } \\
\text { Milk production }\end{array}$ & 65 & 65 & 65 & 65 & 65 & 65 & 65 & 65 & 65 \\
\hline Milk, kg/cow & 6,748 & 6,656 & 6,335 & 7,724 & 7,588 & 6,597 & 6,531 & 6,527 & 6,255 \\
\hline Fat, $\mathrm{g} / \mathrm{kg}$ & 40.6 & 40.9 & 43.9 & 40.0 & 40.1 & 44.5 & 41.0 & 41.1 & 45.6 \\
\hline Protein, g/kg & 34.5 & 35.6 & 36.5 & 35.4 & 35.8 & 37.2 & 34.8 & 35.5 & 36.1 \\
\hline Gestation length, d & 284 & 284 & 278 & 284 & 284 & 278 & 284 & 284 & 278 \\
\hline 42 -d in-calf rate, $\%$ & 54 & 65 & 74 & 54 & 65 & 74 & 54 & 65 & 74 \\
\hline Overall pregnancy rate, $\%$ & 74 & 86 & 93 & 74 & 86 & 93 & 74 & 86 & 93 \\
\hline Total services per cow & 2.07 & 1.79 & 1.61 & 2.07 & 1.79 & 1.61 & 2.07 & 1.79 & 1.61 \\
\hline
\end{tabular}

${ }^{1} \mathrm{HP}=$ high production; $\mathrm{HD}=$ high durability; NZ = New Zealand.

${ }^{2}$ Breeding was initiated at, on average, 60 DIM.

restricted by limitations in feed supply. A total of 99 , $117,117,126$, and 126 animals were used in years 1 , 2, 3, 4, and 5 (585 lactations; Table 2), respectively, divided between strain of Holstein-Friesian and FS. In 2001, all 99 cows were in their first lactation; in 2002, 45 animals were in their first lactation and 72 in their second lactation; in 2003, 9 animals were in their first lactation, 45 in their second lactation, and 63 in their third lactation; in 2004, 27 animals were in their first lactation, 12 in their second lactation, 42 in their third lactation, and 45 in their fourth lactation; whereas in 2005, 27 animals were in their first lactation, 18 in their second lactation, 18 in their third lactation, 36 in their fourth lactation, and 27 in their fifth lactation (McCarthy et al., 2006).

Milk production, live weight, and reproductive performance data over the $5 \mathrm{yr}$ used in the economic modeling are shown in Table 2 (Horan et al., 2004, 2005). The milk production data shown were modified based on differences in reproductive performance observed over the study (Horan et al., 2004) to reflect the expected levels achievable in a stable herd in which the strains will differ in maturity. Hence, reduced reproductive performance resulted in an increased proportion of younger cows in the herd with lower milk yields. Because reproductive performance did not differ significantly between FS (Horan et al., 2004), in agreement with previously published research (Kennedy et al., 2003), all FS were assumed to have the same reproductive performance in this economic analysis.

\section{Economic Analysis}

The Moorepark Dairy Systems model (MDSM; Shalloo et al., 2004a), a stochastic budgetary simulation model, was used to simulate a model farm integrating biological data for each strain in each FS. The model integrates animal inventory and valuation, milk production, feed requirements, land and labor utilization, and an economic analysis.

Land area was treated as an opportunity cost, with additional land rented in when required and leased out when not required for on-farm feeding of animals. Variable costs (fertilizer, contractor charges, medical and veterinarian fees, artificial insemination, silage, and reseeding), fixed costs (machinery maintenance and running costs, farm maintenance, car, telephone, electricity, and insurance), and prices (calf, milk, and cow) were based on current prices (Teagasc, 2004). The feeds offered (grass, grass silage, and concentrate) were determined by the MDSM meeting the $\mathrm{NE}_{\mathrm{M}}$, milk production, and BW change (Jarrige, 1989). The key herd default parameters used in the model farm are shown in Table 3. The herds were compared with an EU milk quota at $468,000 \mathrm{~kg}$ with a reference of $36.0 \mathrm{~g} / \mathrm{kg}$ of fat. The corresponding gross milk price was $22.5 \mathrm{c} / \mathrm{kg}$, based on projections from the latest round of the Common Agricultural Policy, assuming $33.0 \mathrm{~g} / \mathrm{kg}$ of protein with a relative price ratio of 1:2 for fat:protein.

Replacement heifer costs were estimated at $€ 1,319$ (all costs, including capital, land, and labor). All male and $55 \%$ of female calves were sold at 1 mo of age. A differential was placed between the strains in terms of male calf and cull cow value based on the variation in strain BW. The value of male calves of North American origin was $€ 102$ at 2013 predicted prices, compared with €64, respectively, for the lighter NZ strain calves (Keane, 2003). Irrespective of strain, all female calves were assumed sold for $€ 320$. The remaining $45 \%$ of females were sold at 23 mo of age and were bought at the market subsequently for $€ 1,319$ in fixed proportions of 70, 20, and 10 in February, March, and April, respec- 
Table 3. Assumptions used in the model farm ${ }^{1}$

\begin{tabular}{|c|c|c|c|}
\hline Item & $\mathrm{HP}$ & $\mathrm{HD}$ & $\mathrm{NZ}$ \\
\hline Farm size, ha & 40.0 & 40.0 & 40.0 \\
\hline Quota, kg & 468,000 & 468,000 & 468,000 \\
\hline Reference fat, $\mathrm{g} / \mathrm{kg}$ & 36.0 & 36.0 & 36.0 \\
\hline Price of protein to fat & 2 & 2 & 2 \\
\hline Quota lease price, $\mathrm{c} / \mathrm{kg}$ & 4.8 & 4.8 & 4.8 \\
\hline Replacement heifer price, $€$ & 1,397 & 1,397 & 1,397 \\
\hline Labor costs, €/mo & 1,905 & 1,905 & 1,905 \\
\hline \multicolumn{4}{|l|}{ Prices and costs: 2013} \\
\hline Gross milk price, c/kg & 22.3 & 22.3 & 22.3 \\
\hline Reference cull cow price, $€$ & 270 & 270 & 257 \\
\hline Reference male calf price, $€$ & 102 & 102 & 64 \\
\hline Concentrate costs, $€ / t$ & 189 & 189 & 189 \\
\hline Opportunity cost of land, $€ /$ ha & 267 & 267 & 267 \\
\hline
\end{tabular}

${ }^{1} \mathrm{HP}=$ high production; HD = high durability; NZ = New Zealand.

tively. The proportion of cows removed from the herd in each strain accounted for cows that failed to become pregnant by the end of the breeding season as well as voluntary culling and cow mortality.

Three economic scenarios were investigated. In scenario 1 (S1), it was assumed that farmers were constrained by the EU milk quota (i.e., quota applied at the farm level). Farmers with cows producing greater yields would reduce cow numbers to meet the quota exactly (evaluation based on a fixed output). Surplus land was leased out. In scenario 2 (S2), it was assumed that the EU milk quota applied at an industry level, thereby allowing farms with high-producing cows to maintain cow numbers and lease the additional quota required. Where quota leasing was an option, the lease cost was taken at $4.79 \mathrm{c} / \mathrm{kg}$ of milk. In scenario 3 (S3), it was assumed that farmers were constrained by land area but leasing milk quota was possible; therefore, output could be increased through increased feed input.

\section{Risk Analysis}

Stochastic simulation was conducted in the MDSM using the computer software @Risk (Palisade, 2000), which works by a process of Monte Carlo sampling. Monte Carlo risk assessment (also called Monte Carlo uncertainty assessment) specifies a probability distribution for each sensitivity parameter, draws a set of those parameters, and repeats the conventional analysis for multiple draws (Phillips and Maldonado, 1999; Phillips, 2000; Petersen, 2000). A sufficiently large number of simulations were run $(10,000)$ with the same input distributions, so that the probability distribution functions of the outputs were adequately described (Isukapalli et al., 1998).

Stochastic budgeting was used to model the influence of variation in milk price, cull cow value, concentrate cost, and the opportunity cost of land. The values for milk price were obtained from projections from the Food and Agricultural Policy Research Institute-Ireland Outlook 2003 (Binfield et al., 2003). Variation in milk price over the period 1990 to 2003, obtained from the Central Statistics Office (CSO, 2003), was used to determine the spread. The computer program Bestfit (Palisade, 2000) was used to create empirical probability distributions for milk price, cull cow value, and concentrate costs. For milk price and cull cow value, the Bestfit program selected the Extreme value distribution as the optimal distribution for the data. The model picked the Beta general distribution as optimal for concentrate cost. For the opportunity cost of land, the stochastic variables were included as triangular distributions (Hardaker et al., 1997), in which the minimum (€170/ ha), most likely (€267/ha), and maximum (€342/ha) estimates were included based on consultation with a group of experts.

The four stochastic variables were concurrently simulated for the S2 and S3 scenarios with no correlation assumed between variables. Outputs of the analysis are shown in the form of cumulative distribution functions (CDF). The stochastically dominant set was found by comparing the CDF of risky prospects (Thomas et al., 1997). A CDF contains all of the information on the output distribution of the risky prospects and therefore provides a useful decision-making criterion by assessing stochastic dominance. Stochastic dominance is a powerful risk efficiency criterion for comparing risky prospects.

\section{RESULTS}

An economic appraisal within a farmlet study such as this has the benefit that the effects of genetic change are quantified within a controlled management environment in which observed differences can be attributed to genetics, FS, or a combination of these factors.

\section{Current Milk Production Environment (S1)}

Table 4 shows the key herd output parameters from the model for the 3 strains in the MP, HC, and HS FS in scenario 1 . In this scenario, all groups are restricted to a butterfat-corrected fixed quota of $468,000 \mathrm{~kg}$, thereby not requiring the entire 40 ha of land for production. Within each FS, the highest farm profit was realized with the NZ strain, with the farm profit of the HP strain being the lowest and the HD strain intermediate. Within the HP strain, the highest profit was realized in the HC FS (€17,295), with the lowest profit being within the HS FS (€14,232). Regarding the HD and NZ strains, maximal farm profit was realized in the MP FS ( $€ 24,925$ and $€ 27,869$, respectively), the lowest farm 


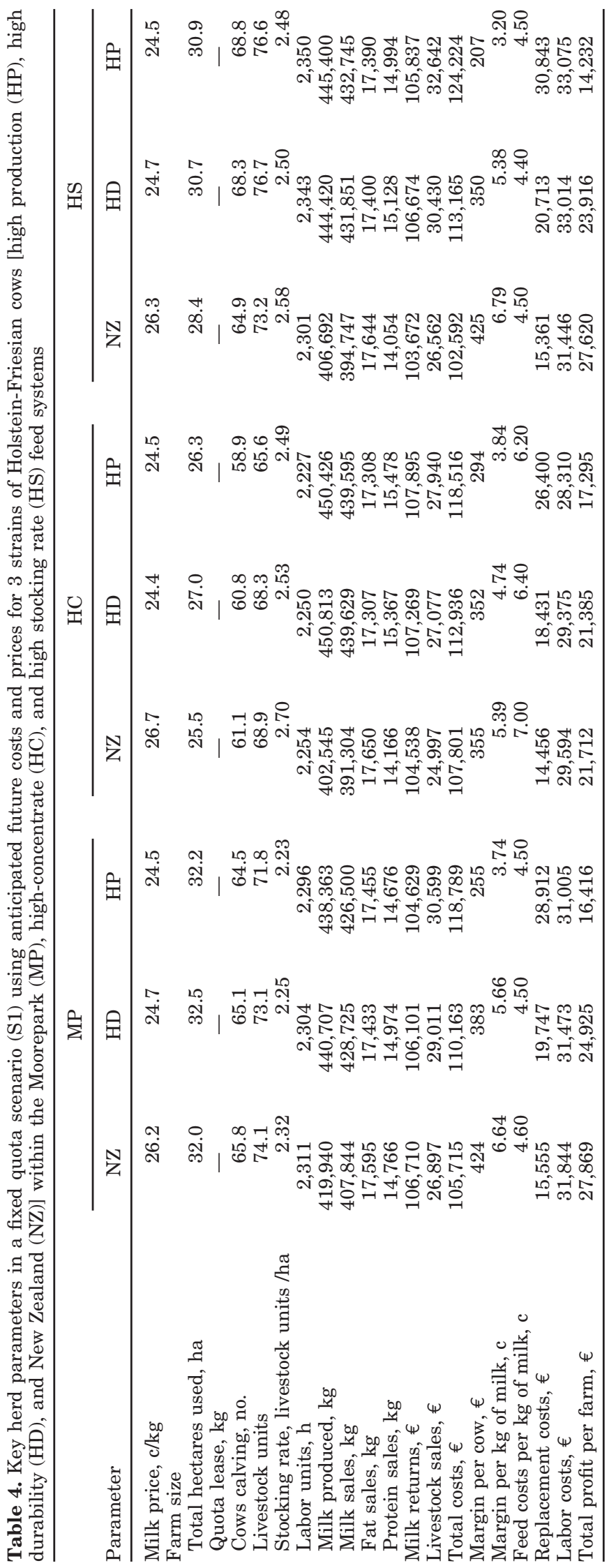

profit was realized in the HC FS (€21,385 and €21,712, respectively), and the HS FS was intermediate (€23,916 and $€ 27,620$, respectively). The increase in farm profit for the HP strain in going from the MP to the HC FS was associated with a large milk production response to increased supplementation in the HC FS, thereby requiring 5.6 fewer cows calving to fill the quota, requiring 5.9 fewer hectares of land, and also resulting in a reduction in both labor and replacement costs. In contrast, the reduction in farm profit for the NZ and HD strains in going from the MP to the HC FS (€6,157 and $€ 3,540$, respectively) was the consequence of a smaller reduction in cow numbers and land requirements caused by lesser milk production responses to concentrate and a reduction in milk returns associated with a disproportionate increase of fat to protein in the HC FS for the NZ strain, resulting in a marginal reduction in profitability in the HC FS. Unlike the NZ strain, which undergoes little change in farm profit going from the MP to the HS FS, the reduction in farm profit for the HD and HP strains was associated with an increase in the number of cows calving, replacement costs, and labor costs.

\section{Quota Leasing Environment (S2)}

The key herd output parameters from the model for the 3 strains in the 3 feed systems, within a quota leasing environment (S2), are shown in Table 5. In this scenario, equal numbers of cows (89.8) were calved for each strain within each feed system. The NZ strain again achieved the highest farm profit in all systems of production, with the HP strain lowest and the HD strain intermediate. The highest profit for the HP strain $(€ 18,846)$ was achieved in the HC FS as in $\mathrm{S} 1$, with the lowest again realized in the HS FS (€14,291). Within this scenario, the HD strain again achieved the greatest farm profit in the MP FS and suffered the largest reductions in profit when moving to the HC FS. The HP strain increased the margin per cow going from the MP to the HC FS, unlike both other strains. Similar to the $\mathrm{S} 1$ scenario, the greatest farm profit for the NZ strain was realized in both the MP and HS FS. The HP and HD strains encountered reductions of $€ 3,177$ and $€ 2,085$ in farm profit in going from the MP to the HS FS. Relative to $\mathrm{S} 1$, the profitability in all cases in this scenario increased.

\section{Limited Land Within Quota Leasing Environment (S3)}

Table 6 shows the key herd output parameters from the model for the 3 strains in the MP, HC, and HS FS in a fixed land area scenario. In this scenario, an equal 


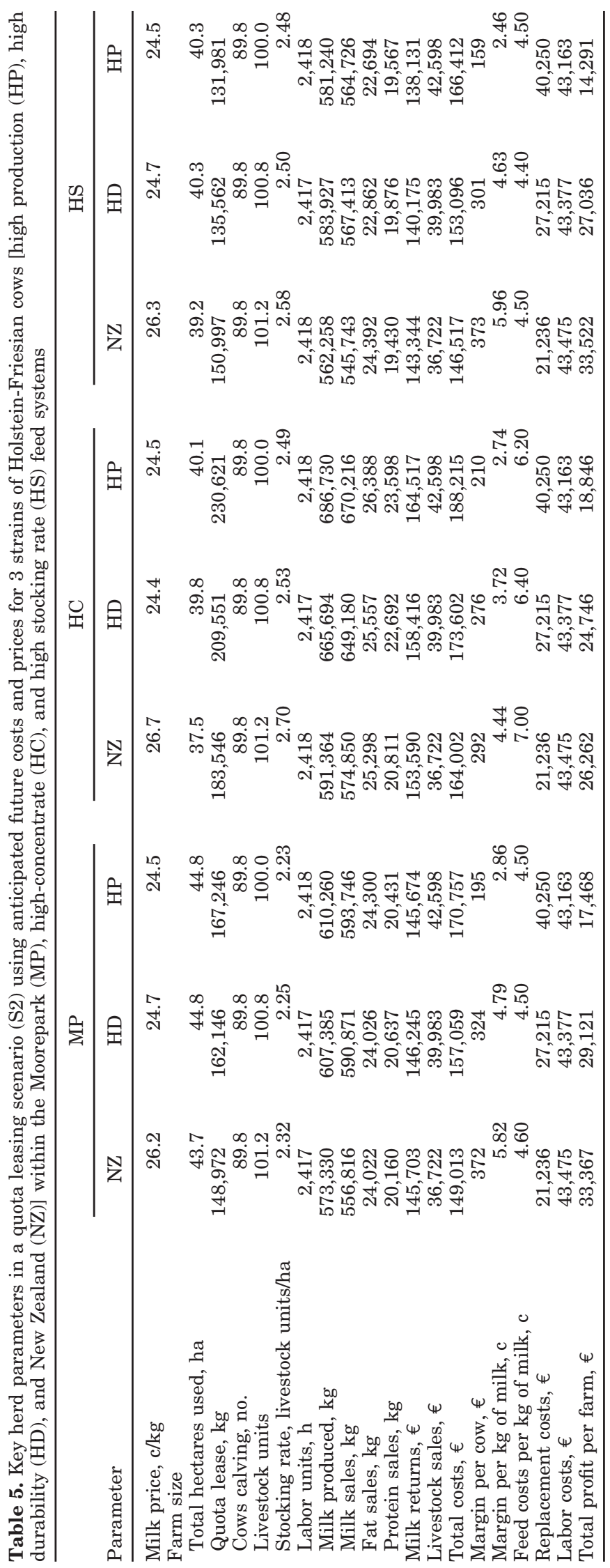

land base (40.0 ha) was available to each farm. The highest farm profit was achieved by the NZ strain in the HS FS (€33,947), with 91.6 cows calving, or 9.4 more than in the MP FS. This resulted in an overall stocking rate of 2.58 livestock units/ha and increases in the margin per hectare of $€ 58$ and $€ 169$ compared with the MP and HC FS for this strain. As in S1 and S2, the HP strain achieved the lowest profit, achieving the greatest profit in the HC FS ( $€ 18,835)$, or $€ 471 /$ ha. Within this environment (S3), cow numbers and feed costs were greatest for the NZ strain in the HC FS, whereas margin per hectare and margin per kilogram of milk were reduced by $€ 111$ and $1.72 \mathrm{c}$, respectively, compared with the MP FS. The HD strain achieved the maximal profit in the MP FS (€27,475), achieving a margin of $€ 687 /$ ha, with the lowest profit for this strain realized in the HC FS, as in both other scenarios. This was related to an increase of 10 cows calving, a reduction in the margin per cow of $€ 68$, and an increase in feed costs of $1.9 \mathrm{c} / \mathrm{kg}$ of milk.

\section{Risk Analysis}

Figure 1 shows the CDF for the spread in farm net profit resulting from variation in milk price, cull cow value, concentrate cost, and the opportunity cost of land for the NZ, HD, and HP strains in the MP, HS, and $\mathrm{HC}$ systems for S2. The graph shows that there was little difference in the distributions of farm profit for the NZ cows in the MP and HS systems, which were stochastically dominant to all other combinations of strains and FS. The HD strain in the MP was next in terms of its stochastic dominance. First-degree stochastic dominance means that the CDF further to the right is preferred. For any given level of risk, there is a greater level of profit, or conversely, for a given level of profit, there is reduced risk when the CDF is further to the right. For all of the other strain and FS combinations, there was some crossing over of the individual CDF lines on the cumulative probability distribution graph. Therefore, the principle of second-degree stochastic dominance must apply, which takes into account the utility function of the farmer in which the farmer's level of aversion to risk will affect the preferred system.

The mean farm profits with the NZ, HD, and HP cows in the MP were $€ 33,210$, $€ 28,764$, and $€ 17,116$, respectively, with $90 \%$ confidence intervals ( 5 to $95 \%$ ) of $€ 12,817$ to $€ 62,218$, €8,008 to $€ 58,411$, and $-€ 3,714$ to $€ 46,724$, respectively (Table 7 ). The mean farm profits with the NZ, HD, and HP cows in the HS were $€ 33,362$, €26,675, and €13,935, respectively, with $90 \%$ confidence intervals (5 to $95 \%$ ) of $€ 13,241$ to $€ 61,997$, $€ 6,663$ to $€ 55,065$, and $-€ 5,770$ to $€ 42,109$, respectively. 


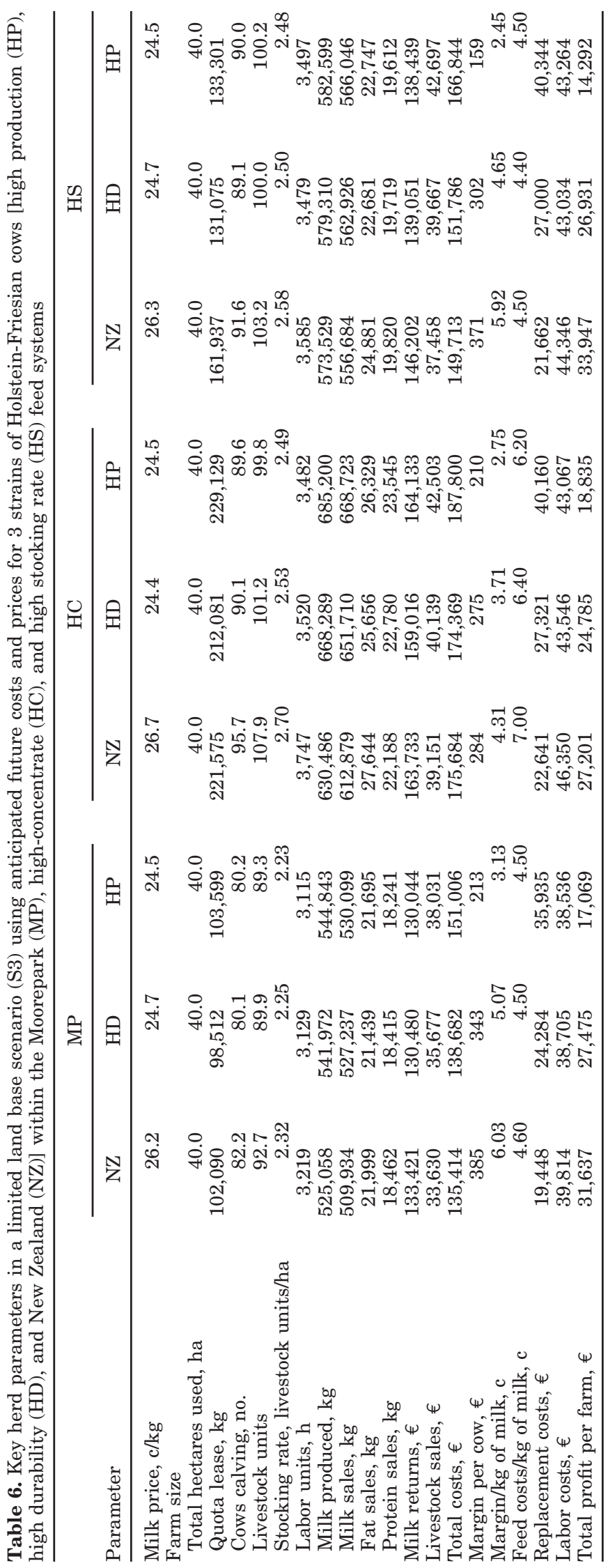

The mean farm profits with the NZ, HD, and HP cows in the $\mathrm{HC}$ were $€ 24,946, € 23,228$, and $€ 17,325$, respectively, with $90 \%$ confidence intervals ( 5 to $95 \%$ ) of $€ 3,477$ to $€ 55,728$, $€ 436$ to $€ 55,592$, and $-€ 6,105$ to $€ 50,753$, respectively.

The CDF for the spread in farm net profit for the NZ, $\mathrm{HD}$, and HP strains in the $3 \mathrm{FS}$ for $\mathrm{S} 3$ is presented in Figure 2. Similar to Figure 1, Figure 2 shows that the NZ cows in the HS feed system were stochastically dominant to all other strain and FS combinations, with the NZ strain in the MP FS next in terms of stochastic dominance. The HP strain in the HS FS was stochastically inferior to all other strain and FS combinations. Similar to S2, the level of stochastic dominance of some of the combinations of strain and FS will depend on the farmer's attitude toward risk. The mean farm profits with the NZ, HD, and HP cows in the MP FS were $€ 31,489$, €27,153, and $€ 16,754$, respectively, with $90 \%$ confidence intervals ( 5 to $95 \%$ ) of $€ 12,822$ to $€ 58,224$, $€ 8,687$ to $€ 53,590$, and $-€ 1,938$ to $€ 43,060$, respectively. The mean farm profits with the NZ, HD, and HP cows in the HS were $€ 33,783$, $€ 26,572$, and $€ 13,937$, respectively, with $90 \%$ confidence intervals ( 5 to $95 \%$ ) of $€ 13,288$ to $€ 62,964, € 6,801$ to $€ 54,464$, and $-€ 5,877$ to $€ 42,082$, respectively. The mean farm profits with the $\mathrm{NZ}, \mathrm{HD}$, and HP cows in the HC system were $€ 25,802$, $€ 23,261$, and $€ 17,318$, respectively, with $90 \%$ confidence intervals ( 5 to $95 \%$ ) of $€ 2,708$ to $€ 58,525$, €526 to $€ 55,929$, and $-€ 6,229$ to $€ 51,043$, respectively.

\section{DISCUSSION}

The productivity and subsequent profitability of a dairy cow is determined by its environment (especially feeding) as well as its own inherent capabilities (genetic potential for production and health traits; Holmes et al., 2002). Both animal and feed factors influencing farm profitability are numerous and differ greatly in significance, depending on the economic characteristics of the production environment. For this reason, the findings of studies investigating the economic influence of alternate genetic selection strategies are often contradictory and the extrapolation of results to alternative production environments is erroneous. This study highlights the large influence of genetic strain and production system on farm profitability within Irish pasture-based production systems. The 3 most prevalent obstacles to expansion were examined in terms of milk quota, cow numbers, and land area.

\section{Influence of Genetic Strain on Farm Profit}

Similar to the current study, previous studies (Shalloo et al., 2004b; Evans et al., 2006) have shown signifi- 


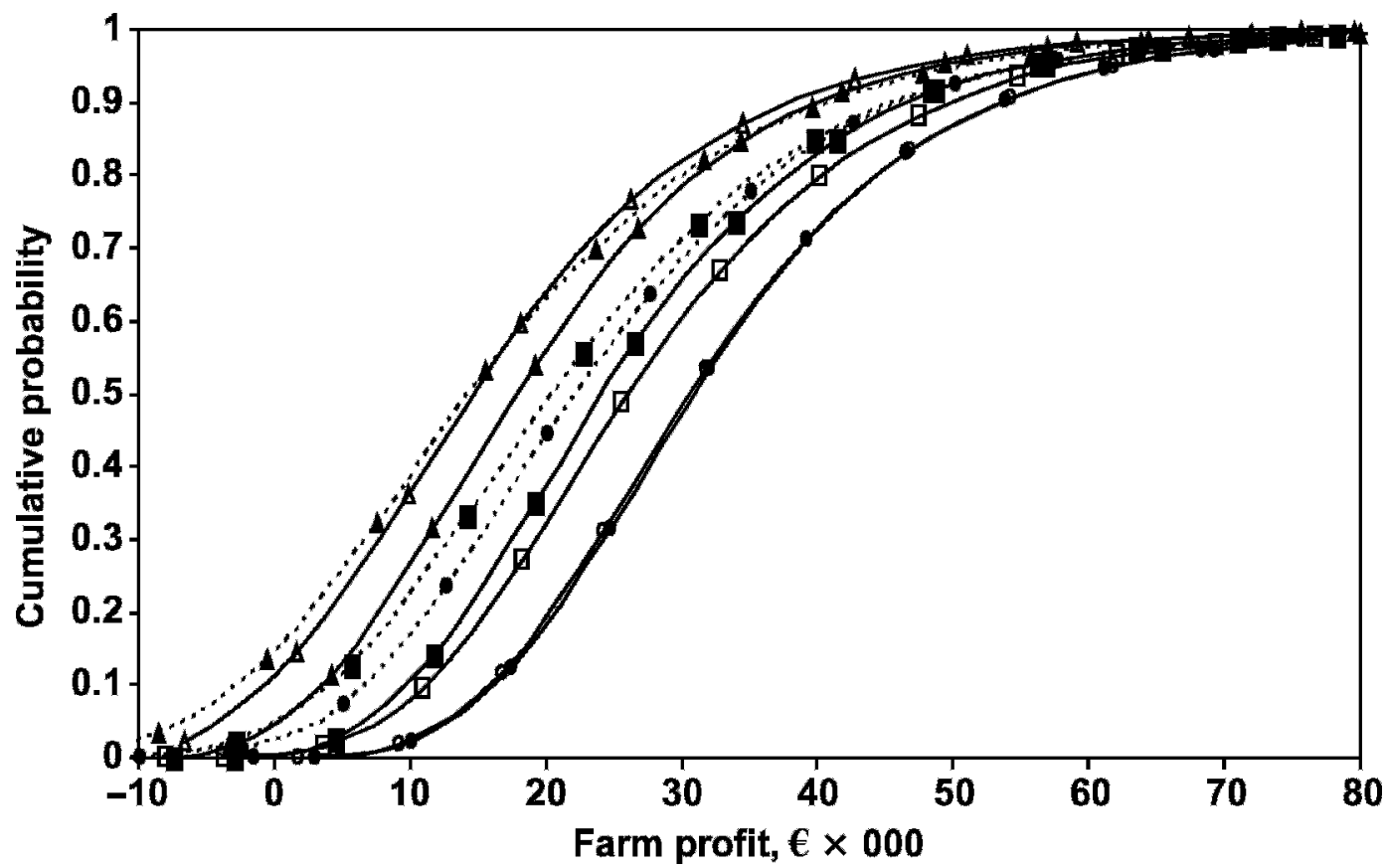

Figure 1. Cumulative probability distribution showing the influence of milk price, cull cow value, concentrate costs, and opportunity cost of land on farm net profit in scenario 2 (European Union milk quota applied at the industry level, thus permitting quota leasing at predicted future prices and costs). $(\boldsymbol{\Lambda}, \triangle)$ High production; $(\square, \square)$ high durability; $(\bullet, \bigcirc)$ New Zealand; open symbols + continuous line, Moorepark; solid symbols + continuous line, high stocking rate; solid symbols + broken line, high concentrate.

cant genetic influences on farm profitability in a variety of pasture-based FS. The results of the present study show that within the economic scenarios investigated for an Irish pasture-based system, the maximal profitability is realized with animals combining high genetic potential for both production and fertility traits (HD and NZ strains) rather than with those selected purely for increased milk production potential (HP strain). These results reinforce the significance of reproductive capacity within pasture-based systems (Schmidt, 1989;
Plaizier et al., 1997). Reductions in economic performance through reduced fertility arise through 1) reduced milk yield per cow per day of herd life, 2) increased culling for reproductive reasons, 3) fewer available replacement heifers, 4) increased semen usage, and 5) added costs of veterinarian interventions (Britt, 1985; Plaizier et al., 1997). Esslemont and Peeler (1993) reported desired annual total culling rates of $18 \%$ to maximize the benefits of age and genetic improvement, whereas Esslemont et al. (2001) reported optimal fi-

Table 7. Effect of strain of Holstein-Friesian and feed system on farm profit $(€)^{1}$

\begin{tabular}{|c|c|c|c|c|c|}
\hline \multirow[b]{2}{*}{ Strain } & \multirow{2}{*}{$\begin{array}{c}\text { Feed } \\
\text { system }\end{array}$} & \multicolumn{2}{|c|}{$\mathrm{S} 2$} & \multicolumn{2}{|c|}{ S3 } \\
\hline & & Profit, € & (CI), € & Profit, € & $(\mathrm{CI}), €$ \\
\hline HP & $\begin{array}{l}\text { MP } \\
\text { HS } \\
\text { HC }\end{array}$ & $\begin{array}{l}17,116 \\
13,935 \\
17,735\end{array}$ & $\begin{array}{l}(-3,714,46,724) \\
(-5,770,42,109) \\
(-6,105,50,753)\end{array}$ & $\begin{array}{l}16,754 \\
13,937 \\
17,318\end{array}$ & $\begin{array}{l}(-1,938,43,060) \\
(-5,877,42,082) \\
(-6,229,51,043)\end{array}$ \\
\hline HD & $\begin{array}{l}\text { MP } \\
\text { HS } \\
\text { HC }\end{array}$ & $\begin{array}{l}28,764 \\
26,675 \\
23,228\end{array}$ & $\begin{array}{r}(8,008,58,411) \\
(6,663,55,065) \\
(436,55,592)\end{array}$ & $\begin{array}{l}27,153 \\
26,572 \\
23,261\end{array}$ & $\begin{array}{r}(8,687,53,590) \\
(6,801,54,464) \\
(526,55,929)\end{array}$ \\
\hline $\mathrm{NZ}$ & $\begin{array}{l}\text { MP } \\
\text { HS } \\
\text { HC }\end{array}$ & $\begin{array}{l}33,210 \\
33,362 \\
24,946\end{array}$ & $\begin{array}{r}(12,817,62,218) \\
(13,241,61,997) \\
(3,477,55,728)\end{array}$ & $\begin{array}{l}31,489 \\
33,783 \\
25,802\end{array}$ & $\begin{array}{r}(12,822,58,224) \\
(13,288,62,964) \\
(2,708,58,525)\end{array}$ \\
\hline
\end{tabular}

\footnotetext{
${ }^{1} \mathrm{HP}=$ high production; HD = high durability; NZ = New Zealand; MP = Moorepark feed system; HS = high stocking rate feed system; HC = high-concentrate feed system; $\mathrm{S} 2$ = scenario 2 (quota leasing); $\mathrm{S} 3$ = scenario 3 (limited land base); CI = confidence interval.
} 


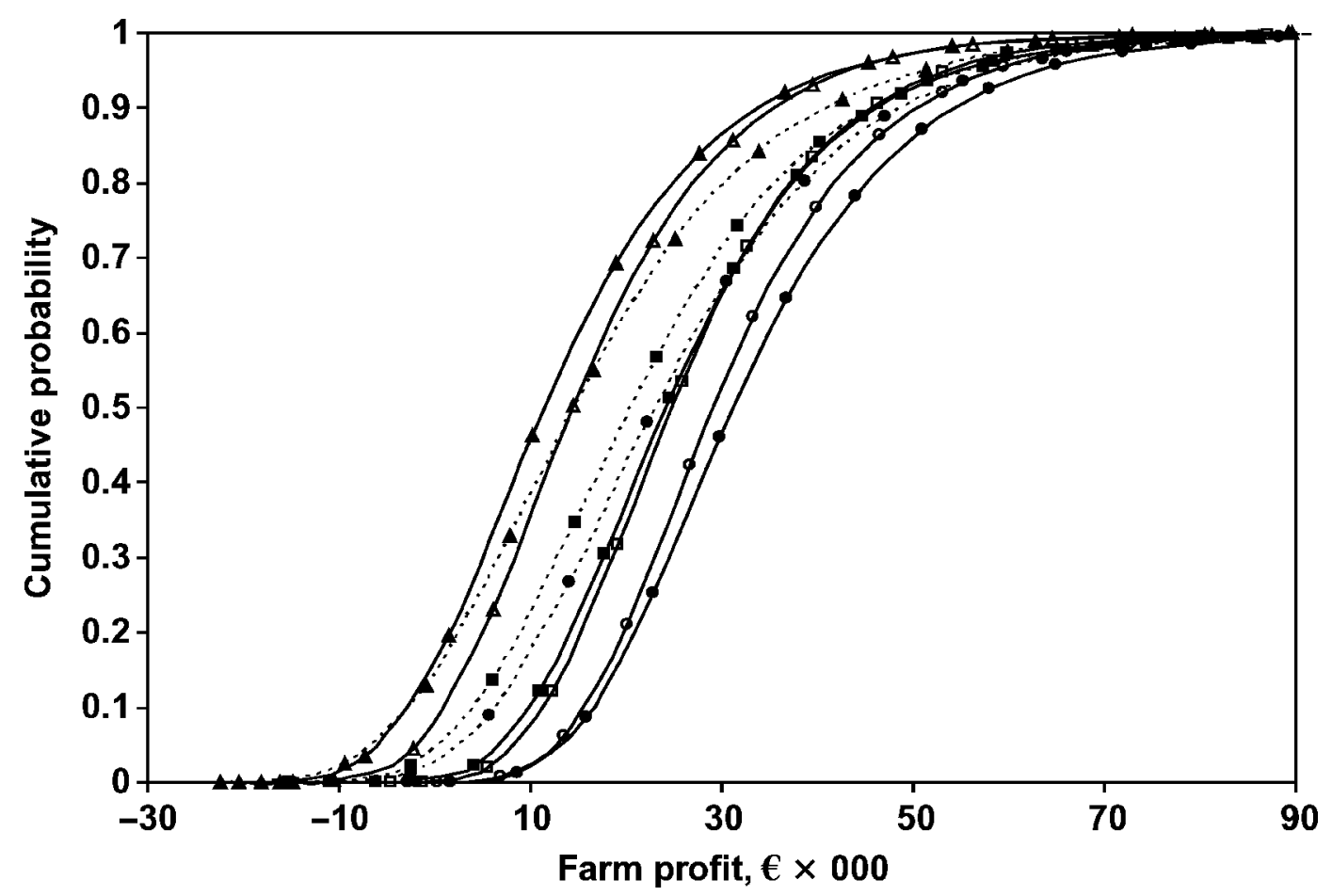

Figure 2. Cumulative probability distribution showing the influence of milk price, cull cow value, concentrate costs, and opportunity cost of land on farm net profit in scenario 3 (European Union milk quota applied at the industry level with a limitation on land availability). $(\boldsymbol{\Lambda}, \triangle)$ High production; $(\boldsymbol{\square}, \square)$ high durability; $(\mathbf{\bullet}, \bigcirc)$ New Zealand; open symbols + continuous line, Moorepark; solid symbols + continuous line, high stocking rate; solid symbols + broken line, high concentrate.

nancial performance as arising with a 365- to 370-d calving interval and a failure-to-conceive culling rate of about $7 \%$.

Antagonistic genetic relationships have been widely reported between genetic merit for milk production and fertility traits; thus, fertility declines with increasing genetic merit for milk yield (Pryce and Veerkamp, 2001). Therefore, selection for increased milk yield without consideration for fertility results in a deterioration of daughter fertility, which has been observed in the Holstein populations in different countries (Philipsson and Lindhé, 2003). As a direct consequence of this relationship, recent Irish commercial farm and research herd studies have observed no association between increased milk yield and farm profitability on Irish pasture-based systems (Evans et al., 2004a; Shalloo et al., 2004b; Evans et al., 2006). Genetic improvement programs must therefore consider all productivity and health traits of economic significance to the production environment. Simm (2000) postulated that the optimal method of selection on a number of traits was to use a selection index that places a weighted emphasis on traits based on their economic importance, taking into consideration the genetic relationship (genetic correlation) among the traits of interest.
In 2001 in Ireland, the EBI (Veerkamp et al., 2002), a profit-based index selecting dairy cows for the predominantly grass-based seasonal calving systems of milk production, was developed to increase the profitability in dairy herds through genetic selection using the precepts of selection index theory (Hazel, 1943). Kahi et al. (1998) stated that the most profitable genotype was that which gives the highest profit per unit of the most limiting input. Within an Irish context, quota is currently the limiting factor (as reflected by the S1), whereas expected changes in the agricultural policy environment are likely to result in the S2 or S3 prevailing in future years. These results and those of Veerkamp et al. (2002) demonstrate that increased farm profitability for Irish dairy farmers, within probable future economic climates, can only be realized where productivity gains are achieved without a detrimental impact on health and welfare traits.

Selection index theory, as outlined by Hazel (1943), is based on the premise that an animal may be poor on one trait and still achieve a high genetic evaluation by compensating based on its superiority on other traits within the index. In this study, the highest EBI (EBI = $€ 80) \mathrm{NZ}$ strain returned the highest profit, the lowest $\mathrm{EBI}(\mathrm{EBI}=€ 52) \mathrm{HP}$ strain returned the lowest profit, 
and the HD strain was intermediate on the EBI ( $€ 57)$ and farm profit in all scenarios investigated, thereby validating the EBI as an accurate genetic selection tool to predict the potential profitability of pasture-based dairy cows in the Irish economic climate. One can also conclude from this result that the overall level of genetic potential of the HD and NZ strains for milk production and health traits (as measured by EBI) rather than their geographic origin, and consequently a genotype $\times$ environment interaction (Kolver et al., 2002; Horan et al., 2005), is responsible for the profitability differential based on the similarity between observed and predicted performance.

In contrast, the large differential in overall profitability between the HP and HD strains in these results is unexpected, given the relatively small differential in genetic potential (EBI of $€ 52$ and $€ 57$, respectively). Although similar product revenue is generated by both strains, the greater replacement costs incurred by the HP strain reduce their overall profitability. Hence, as fertility declined toward, or beyond, a critical point at which overall herd management efficiency was reduced, increased revenue from additional milk was unable to offset this. The increased replacement costs of the HP strain are expected based on their low genetic potential for fertility (fertility subindex $=€ 2$ ); however, it is anticipated based on selection index theory that their superior milk production (milk subindex $=€ 46$ ) would compensate by reducing cow numbers through enhanced per-animal productivity and therefore deliver a similar overall profitability to the HD strain. The increased productivity of the HP strain was not realized because impaired reproductive performance reduced milk production, similar to the observations of Britt (1985). Lopez-Villalobos et al. (2000) showed a dual effect of increased survival on profitability through reduced replacement rates and greater milk yields with larger proportions of mature animals in a simulation study of seasonal calving herds in New Zealand. The reproductive status of a dairy herd has a large impact on the productivity and profitability of that operation. Within spring-calved herds also, late-calving cows usually produce less milk than earlier-calving herdmates, mainly because of shorter lactations (Garcia and Holmes, 1999; McKay, 2000; Stevens et al., 2000).

Fertility is a major factor influencing the profitability of a dairy herd, and its economic value is determined by the prevailing production environment (Harris and Freeman, 1993) and level of fertility (Esslemont et al., 2001). In the United States, an increase in calving interval (Hare et al., 2006) has resulted in an increased weighting on fertility. In New Zealand, which operates a seasonal calving system similar to that in Ireland, $18 \%$ of the relative emphasis within their breeding ob- jective is placed on fertility and longevity (www.aeu.org.nz); however, the average calving interval in New Zealand is around $368 \mathrm{~d}$ (LIC, 2003) compared with 383 $\mathrm{d}$ in Ireland (ICBF, 2003). On this basis, it can be implied that for Irish seasonal pasture-based systems, the economic significance of fertility traits is underestimated and must be considerably increased to reflect the currently low level of fertility in Irish dairy herds as well as the significant influence of fertility on farm profitability. Alternatively, the milk production potential of sires with inferior genetic potential should be revised downward to provide a more accurate estimate of their true production potential within a seasonal production system.

\section{Influence of Feed System on Farm Profit}

Previous research has shown that increased concentrate supplementation at pasture does not influence the reproductive performance of animals when adequate amounts of high-quality pasture are provided (Kennedy et al., 2003; Horan et al., 2004). Similarly, McCarthy et al. (2006) reported no significant effect of feed system on udder health across the $5 \mathrm{yr}$ of this study or on energy balance, as reflected through blood plasma levels of insulin and IGF-I concentrations (McCarthy et al., 2005), whereas Roche et al. (2006) found no effect of feed system on the rate of BCS loss in early lactation. Consequently, where adequate nutrients are supplied in the basal diet, supplementary concentrate feeding can influence overall farm profitability only through its influence on animal production performance. The data collected here suggest that the revenue gains associated with genetic improvement considerably overshadow any influence of FS on farm profitability.

The optimal system of milk production depends greatly on the prevailing economic environment (milk price, feed costs, etc.) as well as the relative availability of the key factors of production (land, milk quota, etc.). Within a milk quota scenario (S1), profit is maximized where production is achieved at a minimal cost, as demonstrated by the comparably greater profitability of the low-concentrate (MP and HS) systems. This is similar to findings by Harris and Freeman (1993), who showed, using a linear programming model, that economic weight for herd life substantially increased in the restrictive quota situation. The limitation on output results in more emphasis being put on efficiency for each liter of milk produced. In a low milk price situation, pasture-based systems were also more favorable, through their capability for low-cost milk production with the achievement of high output per hectare (Penno et al., 1996). 
Within an environment in which milk quota is not a limiting factor (S2 and S3), land availability becomes the next limitation to the pasture-based systems under consideration. Similar to previous studies (Penno et al., 1996), this analysis shows that based on the anticipated reduction in milk price in future years, higher stocking rate (HS) systems will be the most profitable. Such systems will be characterized by their capability for low-cost high milk productivity per hectare with lesser milk production per cow.

The presence of strain of Holstein-Friesian $\times$ feed system interactions in grass-based FS has been reported within the present study in regard to milk production (Horan et al., 2005), grass DMI (Horan et al., 2006), and grazing behavior (McCarthy et al., accepted). This has considerable implications and suggests that the type of cow used to maximize farm profit in lowinput grass-based systems should differ from the type of cow used in greater input systems. The results of this study show that the highest farm profit observed in the study was with animals of lesser milk production with good fertility on an MP or HS FS in all scenarios, whereas the highest farm profit for an HP strain animal was the HC system in all scenarios. Internationally, the HP genotype has been selected aggressively for high milk production in a predominantly confinement environment (Rauw et al., 1998), with its popularity likely attributable to increased productivity over other dairy breeds in a market that has rewarded for milk volume. Ultimately, these data show that whereas the HC system did improve the profitability of the HP animal, the increased profitability was still inferior to that of genetically superior animals across all systems of production. Similar to previous studies (Lopez-Villalobos et al., 2000; Grainger and Goddard, 2004), the data show that under a scenario in which land is limited and stocking rates increase (S3), the economic advantage of the smaller NZ strain will be increased because of the comparably lesser reduction in margin per cow in the HS system.

\section{Influence of Agricultural Policy Change on Farm Profit}

Comparisons of genetic groups or FS must be made on the basis of that which gives the highest profit per unit of the most limiting input (Kahi et al., 1998). Milk quotas were introduced in the EU in 1984, effectively limiting the amount of milk produced from the country and therefore from each individual farm. The economic principles applying to a no-quota environment are substantially different from those that apply within a quota environment (Shalloo et al., 2004b). Where quota is not limiting, output from the farm is maximized through increasing milk sales until marginal revenue from additional milk sales is equal to the marginal cost of the additional milk. The system of milk production operated is therefore governed by the concentrate-to-milk price ratio (Clark and Kanneganti, 1998) and the milk production response to the concentrate supplementation. Where the milk price is high, the systems adopted will maximize realized profitability through increased concentrate supplementation (Soder and Rotz, 2001).

The Common Agricultural Policy is currently undergoing significant change with the most recent reform, the Luxembourg agreement signed into law in June 2003. This has resulted in an anticipated reduction in milk price of $5 \mathrm{c} / \mathrm{L}$ (from 27 to $22 \mathrm{c} / \mathrm{L}$; Binfield et al., 2003) for EU milk producers, with further reductions also likely. It is evident from this analysis that both within the current quota system and also based on projected changes to their production environment, the future viability of Irish dairy farmers depends on the realization of maximal efficiency in pasture-based milk production systems, through the further development of low-cost pasture-based production systems (similar to the MP system) focused on increased productivity. The aim within such a feed system must be to maximize the proportion of grazed grass in the diet, increase utilization, and maintain high intakes (Horan et al., 2006) throughout the grazing season. Complementary genetic selection must therefore deliver animals capable of high productivity from pasture. Based on the current analysis, it is apparent that these animals will be characterized by both high milk production and reproductive potential.

\section{CONCLUSIONS}

The purpose of this paper was to demonstrate the magnitude of variation in profitability between strains of Holstein-Friesian dairy cows, differing in genetic potential for milk production and reproductive performance, across different pasture-based production systems and within various production scenarios and not to recommend any given existing strain of HolsteinFriesian for use in Irish pasture-based systems. Large variation in farm profit arises from various genetic selection strategies and production system choices, with the optimal genetics and production system being the combination that results in the greatest farm profit within that production environment. This study demonstrates how genetic selection for increased milk production (HP strain) in conjunction with increased concentrate supplementation within Irish pasture-based systems will result in reduced profitability in future years relative to selection on a combination of production and reproductive traits (HD and NZ strains) within a 
greater reliance on high-quality grazed pasture. These results validate the use of EBI as a valuable genetic selection tool but suggest that the weighting on fertility traits needs to be increased within the index to reflect the true value of fertility to farm profitability.

\section{ACKNOWLEDGMENTS}

This study is part of a joint project between Dexcel (New Zealand), Massey University (New Zealand), and Teagasc (Moorepark). We would like to acknowledge the support of Colin Holmes (Massey University). We thank the staff of Curtins Farm for their co-operation, care, and management of the experimental animals.

\section{REFERENCES}

Binfield, J., T. Donnellan, K. Hanahran, and P. Westhoff. 2003. The Luxembourg CAP reform agreement: Implications for EU and Irish Agriculture. Pages 1-69 in The Luxembourg CAP Reform Agreement: Analysis of the Impact on EU and Irish Agriculture. Teagasc, Rural Economy Research Centre, Dublin, Ireland.

Britt, J. H. 1985. Enhanced reproduction and economic implications. J. Dairy Sci. 68:1585-1592.

CSO (Central Statistics Office). 2003. Principal Statistics in Relation to Agriculture. Central Statistics Office, Cork, Ireland.

Clark, D. A., and V. R. Kanneganti. 1998. Grazing management systems for dairy cattle in grass for dairy cattle. Page 331 in Grass for Dairy Cattle. J. H. Cherney and D. J. R. Cherney, ed. CABI, Wallingford, UK.

Dillon, P., J. R. Roche, L. Shalloo, and B. Horan. 2005. Optimising financial return from grazing in temperate pastures. Pages 131147 in Utilisation of Grazed Grass in Temporal Animal Systems. J. J. Murphy, ed. Wageningen Acad. Publ., Wageningen, the Netherlands.

Esslemont, R. J., M. A. Kossaibati, and J. Allock. 2001. Economics of fertility in dairy cows. Pages 19-29 in Fertility in the High Producing Cows. M. G. Diskin, ed. Occasional Publication No. 26. British Society of Animal Science, Penicuik, Midlothian, Scotland.

Esslemont, R. J., and E. J. Peeler. 1993. The scope for raising margins in dairy herds by improving fertility and health. Br. Vet. J. 149:537-547.

Evans, R. D., M. Wallace, L. Shalloo, D. J. Garrick, and P. Dillon. 2006. Financial implications of recent declines in reproduction and survival of Holstein-Friesian cows in spring-calving Irish dairy herds. Agric. Syst. 89:165-183.

Evans, R. D., P. Dillon, F. Buckley, M. Wallace, V. Ducrocq, and D. J. Garrick. 2004. Trends in milk production, fertility and survival of Irish dairy cows as a result of the introgression of HolsteinFriesian genes. Page 52 in Proc. Agric. Res. Forum, Tullamore, Ireland. (Abstr.)

Evans, R. D., P. Dillon, L. Shalloo, M. Wallace, and D. J. Garrick. 2004a. An economic comparison of dual-purpose and HolsteinFriesian cow breeds in a seasonal grass-based system under different milk production scenarios. Irish J. Agric. Food Res. 43:1-16.

Garcia, S. C., and C. W. Holmes. 1999. Effect of time of calving on the productivity of pasture based dairy systems: A review. N. Z. Soc. Agric. Res. 42:347-362.

Grainger, C., and M. E. Goddard. 2004. A review of the effects of dairy breed on feed conversion efficiency-An opportunity lost? Pages 77-80 in Animal Production in Australia: Proc. 25th Biennial Conf. Austral. Soc. Anim. Prod., University of Melbourne, Victoria. CSIRO, Victoria, Australia.

Hardaker, J. B., B. M. Huirner, and J. R. Anderson. 1997. Coping with risk in agriculture. $\mathrm{CAB}$ International, Wallingford, Oxfordshire, UK.
Hare, E., H. D. Norman, and J. R. Wright. 2006. Trends in calving ages and calving intervals for dairy cattle breeds in the United States. J. Dairy Sci. 89:365-370.

Harris, B. L., and A. E. Freeman. 1993. Economic weights for milk yield traits and herd life under various economic conditions and production quotas. J. Dairy Sci. 76:868-879.

Hazel, L. N. 1943. The genetic basis for constructing selection indexes. Genetics 28:476.

Hennessey, T., and F. Thorne. 2006. The impact of WTO Doha Development Round on farming in Ireland. Teagasc Rural Economy Research Centre, Athenry, Galway, Ireland.

Holmes, C. W., I. M. Brookes, D. J. Garrick, D. D. S. Mackenzie, T. J. Parkinson, and G. F. Wilson. 2002. Milk Production from Pasture: Principles and Practices. Massey University, Palmerston North, New Zealand.

Horan, B., P. Faverdin, L. Delaby, M. Rath, and P. Dillon. 2006. The effect of strain of Holstein-Friesian dairy cow on grass intake and milk production in various pasture-based systems. Anim. Sci. 82:435-444.

Horan, B., P. Dillon, P. Faverdin, L. Delaby, F. Buckley, and M. Rath. 2005. The interaction of strain of Holstein-Friesian cows and pasture based feed systems on milk yield, body weight and body condition score. J. Dairy Sci. 88:1231-1243.

Horan, B., J. F. Mee, M. Rath, P. O'Connor, and P. Dillon. 2004. The effect of strain of Holstein-Friesian cow and feed system on reproductive performance in seasonal-calving milk production systems. Anim. Sci. 79:453-467.

ICBF (Irish Cattle Breeding Federation). 2003. Irish Cattle Breeding Statistics 2003. Irish Cattle Breeding Society Limited, Shinagh House, Bandon, Co. Cork, Ireland.

Isukapalli, S. S., A. Roy, and P. G. Georgopoulos. 1998. Stochastic Response Surface Methods (SRSMs) for Uncertainty Propagation: Application to Environmental and Biological Systems. Risk Analysis 20:591-602.

Jarrige, R., ed. 1989. Ruminant Nutrition: Recommended Allowances and Feed Tables. John Libbey Eurotext, Montrouge, France.

Kahi, A. K., I. S. Kosgey, V. L. Cardoso, and J. A. M. Van Arendonk. 1998. Influence of production circumstances and economic evaluation criteria on economic comparison of breeds and breed crosses. J. Dairy Sci. 81:2271-2279.

Keane, M. G. 2003. Beef production from Holstein Friesian bulls and steers of New Zealand and European/American descent, and Belgian blue $\times$ Holstein Friesians, slaughtered at two weights. Livest. Prod. Sci. 84:207-218.

Kennedy, J., P. Dillon, K. O'Sullivan, F. Buckley, and M. Rath. 2003. The effect of genetic merit and concentrate feeding level on reproductive performance of Holstein-Friesian dairy cows in a grass based milk production system. Anim. Sci. 76:297-308.

Kolver, E. S., J. R. Roche, M. J. De Veth, L. Thorne, and A. R. Napper. 2002. Total mixed rations versus pasture diets: Evidence for a genotype by diet interaction in dairy cow performance. Proc. N. Z. Soc. Anim. Prod 62:246-251.

LIC (Livestock Improvement Corporation). 2003. Dairy Statistics 2002-2003. Livestock Improvement Corporation, Hamilton, New Zealand.

Lopez-Villalobos, N., D. J. Garrick, C. W. Holmes, H. T. Blair, and R. J. Spelman. 2000. Profitabilities of some mating systems for dairy herds in New Zealand. J. Dairy Sci. 83:144-153.

McCarthy, S., B. Horan, M. Rath, M. Linnane, P. O'Connor, and P. Dillon. The influence of strain of Holstein Friesian and pasturebased feeding system on grazing behaviour, DM intake and milk production of pluriparous dairy cows. Grass Forage Sci. (accepted)

McCarthy, S., D. P. Berry, P. Dillon, M. Rath, and B. Horan. 2006. Effect of strain of Holstein-Friesian and feed system on udder health and milking characteristics. Livest. Sci. doi:10.1016/ j.livsci.2006.08.014

McCarthy, S., J. F. Mee, P. O'Connor, M. Rath, and P. Dillon. 2005. The effect of strain of Holstein-Friesian cow and feeding system on selected plasma metabolic hormones and reproductive performance. Page 52 in Proc. Agric. Res. Forum, Tullamore, Ireland.

McKay, B. 2000. Achieving sustainable reproductive performance. Pages 95-108 in Australian and New Zealand Dairy Veterinari- 
ans Conference, May 2000. T. Parkinson, ed. Veterinary Continuing Education, Massey University, Palmerston North, New Zealand.

Palisade.2000.@Risk Advanced Risk Analysis for Spreadsheets. Palisade Corporation, Newfield, NY.

Penno, J. W., K. A. MacDonald, and A. M. Bryant. 1996. The economics of the no. 2 dairy systems. Pages 11-19 in 48th Proc. Ruakura Farmers' Conf. Dexcel Ltd., Hamilton, New Zealand.

Petersen, B. J. 2000. Probabilistic modelling: Theory and practice. Food Addit. Contam. 17:591-599.

Phillips, C. V. 2000. Applying fully articulated distributions. Am. J. Epidemiol. 151:S41.

Phillips, C. V., and G. M. Maldonado. 1999. Using Monte-Carlo methods to quantify multiple sources of error in studies. Am. J. Epidemiol. 149:S17.

Philipsson, J., and B. Lindhé. 2003. Experiences of including reproduction and health traits in Scandinavian dairy cattle breeding programs. Livest. Prod. Sci. 83:99-112.

Plaizier, J. C. B., G. J. King, J. C. M. Dekkers, and K. Lissemore. 1997. Estimation of economic values of indices for reproductive performance in dairy herds using computer simulation. J. Dairy Sci. 80:2775-2783.

Pryce, J. E., and R. F. Veerkamp. 2001. The incorporation of fertility indices in genetic improvement programmes. Br. Soc. Anim. Sci. Occasional Publ. 26:237-249.

Rauw, W. M., E. Kanis, E. N. Noordhuizen-Stassen, and F. J. Grommers. 1998. Undesirable side effects of selection for high production efficiency in farm animals: A review. Livest. Prod. Sci. 56:15-33.

Roche, J. R., D. P. Berry, and E. S. Kolver. 2006. Holstein-Friesian strain and feed effects on milk production, body weight, and body condition score profiles in grazing dairy cows. J. Dairy Sci. 89:3532-3543.

Schmidt, G. H. 1989. Effect of length of calving interval on income over feed and variable costs. J. Dairy Sci. 72:1605-1611.

Shalloo, L., P. Dillon, M. Rath, and E. M. Wallace. 2004a. Description and validation of the Moorepark Dairy Systems Model. J. Dairy Sci. 87:1945-1959.

Shalloo, L., J. Kennedy, M. Wallace, M. Rath, and P. Dillon. 2004b. The economic impact of cow genetic potential for milk production and concentrate supplementation level on the profitability of pasture based systems under different EU milk quota scenarios. J. Agric. Sci. 142:357-369.

Simm, G. 2000. Genetic Improvement of Cattle and Sheep. CABI, Wallingford, UK.

Soder, K. J., and C. A. Rotz. 2001. Economic and environmental impact of four levels of concentrate supplementation in grazing dairy herds. J. Dairy Sci. 84:2560-2572.

Stevens, J., L. Burton, and J. Rendel. 2000. Induced calving. Page 63-78 in Austral. N. Z. Dairy Veterinarians Conf., May 2000. T. Parkinson, ed. Veterinary Continuing Education, Massey University, Palmerston North, New Zealand.

Teagasc. 2004. Management Data for Farm Planning. Teagasc, Dublin, Ireland.

Thomas, C. V., M. A. Delorenzo, D. R. Bray, R. N. Weldon, R. A. Bucklin, and J. G. Martin. 1997. A stochastic economic analysis of large herringbone and parallel milking parlors. J. Dairy Sci. 80:2418-2428.

Veerkamp, R. F., P. Dillon, E. Kelly, A. R. Cromie, and A. F. Groen. 2002. Dairy cattle breeding objectives combining yield, survival and calving interval for pasture-based systems in Ireland under different milk quota scenarios. Livest. Prod. Sci. 76:137-151. 